\title{
The Social Structure Reform and Long-term Economic Growth of British Economic History
}

\author{
Yang Zheng \\ College of Humanities, Jilin University, Changchun 130012, China \\ 1055074103@qq.com
}

Keywords: new economic history; institutional change; economic growth.

\begin{abstract}
Exploring the basic mechanism of long-term economic growth has been an important and fascinating subject in economics research. In this paper, we use the new economic history analysis paradigm, through studying the British historical evolution, to extract the basic structure affecting the sustained growth of economics. Through the investigation of the rise of the British, we found that the evolution of social structure has a profound and lasting impact on a country's long-term economic growth.
\end{abstract}

\section{Introduction}

Exploring the basic mechanism of long-term economic growth has always been an important subject in the study of economic historians. Once leading in science, technology and other aspects for a long time, being an equal of UK until the 1st century, why has China experienced a rapid decline in modern society and the re-emergence after reforming and opening? Through the study of economic history, we found that the system plays a decisive role in the long-term economic growth and national prosperity.

Douglass C. North is the founder of the new economic history school and the main representative figure. According to the theory of new economic history, in the new classical model, the private benefits and social benefits in economic behaviors equals, the same to private cost and social cost. There isn't diminishing returns in acquisition and application of new knowledge, and the assumption that people's choice is consistent with their expected results is not realistic. North believes that the best state of society is to increase private benefits as much as social benefits as much as possible, in order to provide full stimulation to achieve economic growth. By the way, only in modern, the advances in science and technology are being able to overcome the diminishing returns. In most periods of history, the stock of natural resources is decreasing, and the technical progress is slow.

In this paper, we use the new economic history analysis paradigm, through studying the British historical evolution, to extract the basic structure affecting the sustained growth of economics.

\section{The Evolution of Social Structure, Constitutional System and the Production of the Industrial Revolution of Britain in Modern Times.}

Britain, as an island, although the location protects it form the serious threat of exotic invasions as much as the mainland, but the royal family faces not only the national competitions between different ethnic groups, but also facing the challenge form the Rome church and feudal lords. Its position gradually reversed in competitions with the foreign powers. In 1066, the Norman Conquest brought a more powerful centralized government to the UK. In thirteenth Century; with the improvement of the structure of the tax, the king has the ability to hire a standing army to weakening the vassal power, and the royal court gradually expanded its civilian jurisdiction in comparison with the Lord; Henry VIII (1509-1547) issued "against papal authority" (1536), abolished the power of Pope in UK; the tax privilege of tolls were limited to few years. In short, with the power of British royal family increasing and the power of British aristocracy weakening, the aristocracy was unable to establish independent kingdom itself, only collective struggles can take more power and interests. The United nobilities often set that to restrict the king's force and act in accordance with the law and habit as the goal of 
collective struggle. Therefore, in struggles with the feudal monarchy, the royal family had established the content of balanced power very early.

The state power has been constrained, mainly during to the division of the social structure of the United Kingdom in seventeenth Century. The merchant has gained their wealth in business and hope that the prosperity of country will protect their interests. Most of them are close to the Parliament and famous for their political representative which is the Whig. The traditional local forces against the merchant support the Royal in the civil war and resolutely oppose foreign wars, government debt and land tax. Linked closely to the church the local forces has formed the basic components of the Tory after the glorious revolution. The Whigs behalf of the merchant benefit believe that only the lack of income could force the King who is badly in need of money to convene parliament, so that they will have the opportunity to bargain with the royal family. However, the royal family seeks to bypass parliament for the insufficient found. This mistrust system ultimately lead to conflict with each other. In late 1670s, the Whigs attempted to exclude James (the king's brother) from the ranks of the heir, this action reduces the Whig support rate and thus deprived the Whig voting right in parliament. The royal family won enough support on the other way, but the royal family's subsequent behavior has caused the opposition of Tory as their supporters. James supports the Catholic and attempts to build a Catholic army. With Tories closely connected with the Church refusing to cooperate, James turned to launch a further constitutional movement against the whole country. The great damage that James made to representative system alerted the Tories and reduced the value of support for the king. The struggles between Whig and Tory reflects the conflict between the Parliament and the royal family, and the predatory behavior of royal ultimately make itself isolated completely by their supporters of the Tories who finally turn to support the parliament.

During this period, the bargaining power of the merchant class was also increased with the enhancement of its economic strength. Just like Holland, the British hasn't developed a set of authoritarian power in the trade of Atlantic, so as to that the profits of the business class obtained in the Atlantic is very substantial and in successive years of growth. Estimates from Daron Acemoglu, Simon Johnson, and James A Robinson suggest that profits from the trade of Atlantic can be ignored before 1575, in 1576-1600 about \$40 thousand annually in average, in the 1601-1650 about \$200 thousand annually in average, in 1651-1675 about $\$ 500$ thousand annually in average, with the expansion of the slave trade and the sugar trade in 1676-1700, the profits rise to an average of $\$ 900$ thousand each year, in 1701-1-750 about $\$ 700$ thousand annually in average, and by the late eighteenth Century about S00 million dollar annually in average[3].At the same time, in early seventeenth Century, 10 thousand dollars is quite rich personally, the minimum investment of \$2 thousand will be able to become a director of East India Company. Compared to the personal property of merchants and nobles in this period, we can see that the plunder in the trade of Atlantic is quite considerable.

With the strengthened power, when facing country's predatory behavior, the merchant class is able to achieve their own interests through the bargain. Because of the country's predatory behavior leading to conflicts of interest between the merchant class and the king, the merchant class requires to limit the kingship to protect private property. After fierce struggles against the king, they gained their legal political power. In the English Civil War of 1642 and glorious revolution of 1688, the rich merchants and aristocrats have invested a large number of military expenditure to support the parliament to defeat the king so as to establish a limited monarchy-"constitutional monarchy". In 1689 the "bill of rights" was passed, so the parliament reestablished the absolute power of adding new tax and could supervise the spending of the government ${ }^{[4]}$. The royal privilege was limited by the common law, and the control of the judiciary was abolished. With the independence of the judges strengthened, the common law courts which were in favor of private property established its authority status. The constitutional reform agreed on the provisions set a series of principles with boundaries relatively clear for the royal family's behavior. Through the coordination between citizens of civil society, the reform enhanced the collective action of citizens, improved the ability of public punishment of Royal predatory behavior, but also greatly limited the royal family to improve the ability of their abuse of power by the diversity of views among citizens. Finally, the monarchy get tax 
revenue, the parliament wins the right of Taxation, the businessmen get external protection of property rights. The control of the property was transferred from the royal family to the merchant and a Council of landed nobility, so as to limit the Kingship to protect private the property rights and market competition.

Although the parliament lays down the form of new political system, it has not taken over the right to provide public goods of the government, which reduces the possibility of infringement of Parliament. In 1641, a centralized agency who has the right to modify the royal family was canceled, to prevent the king or parliament to take the similar infringement. The Whig party had limited the Royal administrative intervention to the common law courts by the parliament, so the political independence of the courts limited the right to abuse the power of parliament, which ensured the authority that the court is not subject to any challenge in the economic activities. With constitutional reform abolished the Royal's control of the judiciary, the independent judicial system has improved the ability to raise loan financing of the government. The power balance and successful cooperation of the Royal and parliamentary significantly limited the public self-interest, not only England won the war, but also achieved the international power. With the effective access to resources to a hitherto unknown extent, the England established its hegemony in the international relations.

In the financial sector, with a set of effective government credit system for the declaration of respect for the authority of the constitution, London completed the financial revolution through the political turmoil of seventeenth Century. According to the Sterling gold fixed price in the 1717, after more than 200 years, beside of the brief interruption from 1797 to 1819 and 1914 to 1925, the England always adheres to the gold standard and the traditional gold parity until 1931. The stability of the value of the pound is clearly a commitment to national credit in England, thus to ensure the status of international financial center of London.

\section{Discussions and Conclusion}

Through the analysis of the economic history of the United Kingdom, we find that the development of an efficient economic organization in Western Europe has become the cause of the rise of the western world. However, due to that the costs of the establishment and implementation of ownership may outweigh the benefits, and the lack of technology to stop the "free rider" behavior or forced third party in the transaction cost share, with externalities, people don't have the power to strive for the innovation of property right system. The costs of the establishment, regulations and implementation of the ownership for the nation was far less than that for social groups. Therefore, non-governmental organizations have incentive to submit the right of providing public goods to countries with economies of scale, and buy public goods provided by the state through the exchange of taxes. But technological changes and more efficient market expansion will change the relative factor prices and opportunity cost of the voters, and may lead to increased conflicts with the ownership structure of increasing rent of rules to the maximum, which may cause the state protection for some ownership of hindering economic growth, and institutional arrangements of production are not guaranteed to occur. Form the redistribution of society from the ancient dynasty of Egypt to the slavery society in Greece and Rome and feudal manor, dualistic structure failing to reach balanced between the state and society has become the root cause of countries failing to enduring economic growth.

Therefore, the arrangement of efficient property rights system is only one kind of the variety of possible efforts in the interaction between national and social. This similar unofficial civil society has appeared in many societies, but not every society has the ability or opportunity to reach a balance between state powers. It is not possible to define the right boundary between state and society once, so we need to make institutional bargaining to promote institutional change constantly. In Britain, with the growing strength of the civil society and their conflicts with feudal lords, the demand for centralized state of the central government has appeared. At this moment, with the stable property rights, citizens have had the ability to negotiate with the government in the process of protection of property rights transferring to the country, and established the capacity of effective allocation of 
social resources, integration of the special interests of the lower, expression and mediation of interests by upper structure $b$ through collective actions. In this process, the new class through the constitutional revolution completely changed the country's predatory behavior, and with the establishment of the legal system to provide the protection of property rights and regulation of market transaction, and established the efficient economic organization. Complete property rights system has caused the scale of elements and product market expanding and specialization deepening, and organizational revolution greatly reduced the expansion of transaction cost brought by specialization deepening, which fully mobilizes and motivates the social resource oriented to technological innovation. With huge pressure on the other countries, in the end like France of authoritarian state the changes in society has occurred under the constants conflicts of social structure composed of nobility and civilian polar opposites, and completed the transition from traditional society to modern society, established a modern system structure and promoted technological innovation, from then on the industrial revolution and economic take-off came into being one after another in western countries.

\section{References}

[1] North, D. C. (1990). Institutions, institutional change and economic performance. Cambridge university press.

[2] Cooper, R. N. (1996). World economic primacy, 1500-1900. Foreign Affairs.

[3] Acemoglu, D., Johnson, S., \& Robinson, J. A. (2005). Institutions as a fundamental cause of long-run growth. Handbook of economic growth, 1, 385-472.

[4] North, D. C. (1994). Economic performance through time. The American economic review, 84(3), 359-368.

[5] Hicks, J. (1969). A theory of economic history (Vol. 163). Oxford: Oxford University Press.

[6] Pounds, N. J. G. (2014). An economic history of medieval Europe. Routledge.

[7] North, D. C., \& Thomas, R. P. (1973). The rise of the western world: A new economic history. Cambridge University Press. 